\title{
IFRS 16 AND ITS IMPACTS ON AVIATION INDUSTRY
}

\author{
Alžběta Veverková ${ }^{1}$ \\ ${ }^{1}$ Department of Accounting and Taxes, Faculty of Business and Economics, Mendel University in Brno, \\ Zemědělská 1, 61300 Brno, Czech Republic \\ To link to this article: https://doi.org/10.11118/actaun201967051369 \\ Received: 4. 9. 2017, Accepted: 6. 12. 2018
}

To cite this article: VEVERKOVÁ ALŽBĚTA. 2019. IFRS 16 and its Impacts on Aviation Industry. Acta Universitatis Agriculturae et Silviculturae Mendelianae Brunensis, 67(5): 1369-1377.

\begin{abstract}
Current differences between the accounting models for a financial and an operating lease and their critics from the users of the financial statement forced the IASB issued a new Leases Standard, IFRS 16, which supersedes IAS 17 Leases and its related interpretations in January 2106. IFRS 16 will eliminate dual accounting model for lessees and it is assumed to have significant business implications, especially from lessee's point of view. The paper focuses on quantification of the impact of IFRS 16 on selected financial statement items and financial analysis ratios of fifteen European airlines. The research is also concerned with comparison of the article outputs with the previous cases studies. The paper confirmed that lease capitalization under IFRS 16 will have a material impact on the reported numbers in the balance sheet and income statement and result in significant changes to return and leverage ratios.
\end{abstract}

Keywords: IFRS 16, IAS 17, operating lease, capitalization

\section{INTRODUCTION}

In January 2016, after ten years long joint project of the International Accounting Standards Board (IASB) and the Financial Accounting Standards Board (FASB), the IASB issued a new Leases Standard, IFRS 16, which supersedes IAS 17 Leases and its related interpretations (IFRIC 4, SIC-15 and SIC-27). Entities are obliged to apply IFRS 16 from 1 January 2019 with possible early application for entities that have adopted IFRS 15, Revenue from Contracts with Customer. The reasons leading to the issue of new accounting principles for the recognition, measurement, presentation and disclosure of leases were long-term dissatisfaction of the users of the company financial statements with current standard IAS 17.

The biggest problem of the current lease standard is the existence of two different accounting models for financial and operating leases. Different approaches to the reporting of the financial and operating leases do not allow the necessary comparability of company financial statements for effective decision-making process. Under IAS 17 the financial lease is considered to be a method of financing. Therefore, it is reported both in the balance sheet (leased assets recorded as the lessee's property and lease obligations) and in the income statement (interest costs recorded as the part of financial expenses). However, operating leases are reported only in the income statement, as operating costs. For this reason, the operating lease is often called off balance sheet lease.

Based on the results of a large number of studies (e.g. Lubove, 2002; Feldman, 2002; Franzen, Kimberly and Simin, 2009), it can be concluded that entities prefer operating lease to finance. The lessees prefer operating leases because it allows them to create a „better“ financial picture of the company due to the absence of a lease liability in the balance sheet and all the risks associated with the lease is borne by the lessor (Lubove, 2002). High level of leverage ratios is understood by the lender as a signal of the potential financial risk too. For this reason, some companies use operating leases as a way to hide their liabilities and assets. At the 
same time the entities achieve better profitability ratios such as ROA, ROE or net profit. According to Duke, Hsieh, Su (2009) unrecognized lease liabilities represent $11.13 \%$ of reported liabilities and unrecognized leased assets 3.97\% of the reported assets. In 2005, the US Securities and Exchange Commission (SEC) estimated that US public companies might have approximately 1.25 trillion of off balance sheet leases (IASB, 2016). The case study also states that the size of the lease commitments, which are not reported on the balance sheet, is at least three trillion US dollars in case of quoted companies using IFRS or US GAAP. Feldman (2002) says that, in general operating leases are preferred in sectors where assets of high financial value are leased. Good examples are airlines and shipping companies.

The individual users are forced to capitalize operating leases individually for their financial analysis purposes. Due to the fact that these adjustments are currently based entirely on the subjective view of the user of the reports, it is possible to obtain very different results for the same company. Different capitalization models are also used by ratings agencies which should provide independent, high quality and, above all, comparable ratings.

The new lease accounting standard will substantially change the accounting for lease transactions and is likely to have significant business implications, especially from lessee's point of view. IFRS 16 means the end of off balance sheet leases because the new standard will eliminate dual accounting model for lessees which distinguishes between on-balance sheet finance leases and offbalance sheet operating leases and will introduce a single accounting model that is similar to current finance lease accounting. Almost all leases will be recognized in the balance sheet, with a right-ofuse asset and financial (lease) liability. IFRS 16 will not be applied for short-term lease within twelve months and for the lease where the leased asset is low value, such as a personal computer. There is little change for the lessors. They will continue to classify leases as finance and operating leases.

IFRS 16 will have a significant effect on many companies' financial statements as well as their key accounting metrics such as debt and gearing ratios, EBITDA (this will increase as rental expense is replaced by interest, depreciation and amortisation). The management will have to find a way how clearly explain the impact of changes to stakeholders. It is assumed that major effect should be seen at the companies with a large number of operating leases because these would now be accounted for in the same way as finance leases. According to PWC (2016) the aviation industry will be a second sector most affected by the new rules among the world-wide companies using IFRS as their financial reporting framework. The case study confirmed not only significant differences in the effects of lease capitalisation by industry and but also among individual entities within the same industry.

The main aim of the paper is quantification of the impact of IFRS 16 on selected financial statement items and financial analysis ratios in aviation industry. The operating lease is significantly used for the aircraft rentals. According to Tocci (2016) about $40 \%$ of jet aeroplanes currently flying with commercial airlines around the world are on lease with a prediction to grow to $50 \%$ by the year 2020. The paper also focuses on searching the correlation between the achieved results and airline's lease structure. The paper is concerned with comparison of the article outputs with the previous cases studies which focused on impacts of IFRS 16 or the capitalization models (IASB, 2016; Wong and Joishi, 2015; De Villiers and Middelberg, 2013; Kilpatrick and Wilburn, 2006; Bennet and Bradbury, 2003; Beattie et al., 1998; Imhoff, Lipe, and Wright, 1997 and 1991).

\section{MATERIALS AND METHODS}

The publically available financial statements of fifteen European airlines are used in the research. The airlines have headquarters in the European Union, Switzerland and Norway and their financial statements comply with IFRS Standard. The chosen airlines are different not only in the size of total assets but also in the percentage of usage the operating lease (Tab. I). The companies which use operating lease more than $65 \%$ are marked as the companies with material off balance sheet leases. Most of the financial statements are denominated in euro. At the rest of the report, the exchange rate for the date 12. 8. 2017 was utilized. The accounting data from the financial period 2010-2016 are used for calculation.

To determine the effects of the IFRS 16 it is firstly necessary to capitalize unrecorded leased assets and lease liability in accordance to the new methodology. Then, the value of capitalized operating leases is added to book value of assets and to financial liability. IFRS 16 defines that the

I: Lease structure in \%

\begin{tabular}{ccccccccccccccccc}
\hline Company & $\mathbf{1}$ & $\mathbf{2}$ & $\mathbf{3}$ & $\mathbf{4}$ & $\mathbf{5}$ & $\mathbf{6}$ & $\mathbf{7}$ & $\mathbf{8}$ & $\mathbf{9}$ & $\mathbf{1 0}$ & $\mathbf{1 1}$ & $\mathbf{1 2}$ & $\mathbf{1 3}$ & $\mathbf{1 4}$ & $\mathbf{1 5}$ & Total \\
\hline FL & 19.7 & 77.8 & 2.2 & 63.0 & 54.3 & 31.2 & 15.7 & 4.3 & 30.3 & 35.9 & 16.3 & 3.58 & 61.0 & 90.1 & 51.00 & 31.2 \\
OL & 80.3 & 22.2 & 97.8 & 37.0 & 45.7 & 68.8 & 84.3 & 95.7 & 69.7 & 64.1 & 83.7 & 96.42 & 39.0 & 9.9 & 49.00 & 68.8 \\
\hline
\end{tabular}

Source: author's calculation based on Annual Reports 
leased asset is equal to the present value of the total future minimum lease payments and at the same time the value of leased assets is equal to the lease liability at the lease inception. IFRS 16 states that it is necessary to work with the individual interest rate which represents the borrowing costs of a particular company. Unfortunately, most of the companies do not disclose the information of the individual rental interest rate, including the implicit interest rate. There are two ways how to deal with this problem. The first option is to choose a constant interest rate for all companies. The second option, which appears in the works of Fito, Moya and Orgaz (2011), Fülbier, Silva and Pferdehirt (2008), is to work with companies that have published their individual interest rates in their financial statements. In other cases, it is necessary to determine the interest rate on the basis of the median published interest rates. In the paper the mix of these two methods is used and the fixed discount rate of $4.2 \%$ is set.

Each of the company preparing its financial statement in accordance with IFRS requirements has to disclose little information related to the lease agreement. IAS 17.56 defines that the entities are obliged to present their future minimum lease payments in the following structure: for the next year, for the year two to five and for the more than five years. However, most of the airlines disclose only total future minimum lease payments for the year two to five in Notes of its financial statement. So the adjustment of the data was necessary for the calculation. There are several ways how to calculate annual future minimum lease payment for the period. The method of Bennett, Bradbury (2003) was chosen. They assumed that all lease payments over the lease period are equal, so the annual lease payment are calculated by dividing the total minimum lease payment between year two and five by four.

The next step is considered to remove implicit lease interest expense from operating expenses to financial expenses. The determination of interest expenses is based on book value of the lease liability multiplied by the interest rate $4.2 \%$. The calculation of depreciation costs comes from the assumption that useful life of aircraft is 20 years and building is 45 years. The determination of the useful life is based on similar principles such as setting the interest rate. Some companies in the sample have published exact information about the useful life of assets, some of them have disclosed only range of years for each categories of the asset and the others have not published any information.

The new approach will influence several balance sheet and income statement items and numerous financial metrics whose structure is based on the affected items. The paper focuses on total assets, noncurrent liabilities, shareholder's equity, depreciation costs, interest expenses, EBIT and EBITDA. The quantification of the impact of IFRS 16 is expressed as the percentage changes in these financial ratios. Return on asset (ROA), Return of equity (ROE) and Profit Margin demonstrate changes in the profitability of companies' assets and equity. Leverage ratios are represented by Total Debt to Total Assets (D/A) and debt-to-equity ratio (D/E) indicating the relative proportion of shareholders' equity and debt used to finance a company's assets. Current Ratio (CR) is an example of liquidity ratio that measures a company's ability to pay shortterm obligations. These Financial metrics were also chosen due to possible comparison to the previous studies.

$$
\begin{aligned}
& R O A=\frac{E B I T}{\text { Total assets }} . \\
& R O E=\frac{E B I T}{\text { Equity }} .
\end{aligned}
$$

Profit Margin $=\frac{\text { EBIT }}{\text { Turnover }}$.

Total Debt to Total Assets $=\frac{\text { Total liabilities }}{\text { Total assets }}$.

Debt to Equity Ratio $=\frac{\text { Total liabilities }}{\text { Shareholdres' Equity }^{\prime}}$.

Current Ratio $=\frac{\text { Current Assets }}{\text { Current Liabilities }}$.

Maximum, minimum and median were set for each calculated items.

\section{RESULTS}

\section{Effects of IFRS 16 on Statement of Financial Position}

IFRS 16 requires lessee to record leased asset (right - of - use) and lease liabilities in its balance sheet for all leases except for short - term leases and leases of low - value assets. The newly recognised leased asset will be part of fixed asset and the lease liability will be either non- current or current financial liability depends on timing of lease payments (IASB, 2016). Tables (Tab. II and III) confirmed increase in total assets and non- current liabilities. In case of the total assets, median increase is $25.71 \%$. The company 3 and 12 represent the biggest growth (169.46\% and 144.27\%). Non - current liabilities change by $9.89 \%$. The main adjustment it can be 
II: The effect of IFRS 16 on Total assets

\begin{tabular}{c|rrr}
\hline Company & Median & Maximum & Minimum \\
\hline \multirow{yyy}{*}{1} & $58.85 \%$ & $87.54 \%$ & $27.982 \%$ \\
\hline 3 & $8.42 \%$ & $9.32 \%$ & $7.81 \%$ \\
\hline 4 & $169.46 \%$ & $299.63 \%$ & $101.39 \%$ \\
\hline 5 & $47.61 \%$ & $55.53 \%$ & $33.24 \%$ \\
\hline 6 & $24.25 \%$ & $31.21 \%$ & $20.97 \%$ \\
\hline 7 & $11.39 \%$ & $12.80 \%$ & $7.61 \%$ \\
\hline 8 & $26.09 \%$ & $75.82 \%$ & $21.67 \%$ \\
\hline 9 & $31.31 \%$ & $45.83 \%$ & $18.53 \%$ \\
\hline 10 & $37.11 \%$ & $46.17 \%$ & $26.96 \%$ \\
\hline 11 & $7.49 \%$ & $9.08 \%$ & $7.33 \%$ \\
\hline 12 & $144.27 \%$ & $161.75 \%$ & $91.29 \%$ \\
\hline 13 & $5.91 \%$ & $7.72 \%$ & $3.83 \%$ \\
\hline 14 & $0.34 \%$ & $0.94 \%$ & $0.07 \%$ \\
\hline 15 & $16.27 \%$ & $28.16 \%$ & $12.13 \%$ \\
\hline Total & $25.17 \%$ & $38.52 \%$ & $19.75 \%$ \\
\hline
\end{tabular}

Source: author's calculation based on Annual Reports

again see at company 1, 3, 8 and 10 . These entities are the examples of companies with major off balance sheet.

Contrary, the negative change in value of Equity (Tab. IV) it is possible to see. Carrying amount of the leased asset would typically decrease more

IV: The effect of IFRS 16 on Shareholder's equity

\begin{tabular}{c|ccc}
\hline Company & Median & Maximum & Minimum \\
\hline 1 & $-9.59 \%$ & $-12.92 \%$ & $-7.00 \%$ \\
\hline 2 & $-1.01 \%$ & $18.44 \%$ & $-0.88 \%$ \\
\hline 3 & $-77.39 \%$ & $-250.33 \%$ & $-23.67 \%$ \\
\hline 5 & $-67.51 \%$ & $-155.43 \%$ & $-11.20 \%$ \\
\hline 6 & $-1.79 \%$ & $-3.86 \%$ & $-1.42 \%$ \\
\hline 7 & $-1.27 \%$ & $-1.76 \%$ & $-0.93 \%$ \\
\hline 8 & $-3.65 \%$ & $-2.70 \%$ & $-2.70 \%$ \\
\hline 9 & $-17.62 \%$ & $-14.04 \%$ & $-65.61 \%$ \\
\hline 10 & $-9.42 \%$ & $-12.16 \%$ & $-4.25 \%$ \\
\hline 11 & $37.11 \%$ & $46.17 \%$ & $26.96 \%$ \\
\hline 12 & $-2.10 \%$ & $-3.05 \%$ & $-1.36 \%$ \\
\hline 13 & $-40.34 \%$ & $-86.30 \%$ & $-20.13 \%$ \\
\hline 14 & $-0.84 \%$ & $-0.65 \%$ & $-1.12 \%$ \\
\hline 15 & $-0.09 \%$ & $-0.20 \%$ & $-0.03 \%$ \\
\hline Total & $-4.15 \%$ & $-5.82 \%$ & $-3.83 \%$ \\
\hline
\end{tabular}

Source: author's calculation based on Annual Reports
III: The effect of IFRS 16 on Non - current liabilities

\begin{tabular}{c|rrr}
\hline Company & Median & Maximum & Minimum \\
\hline 1 & $40.04 \%$ & $55.81 \%$ & $27.45 \%$ \\
\hline 2 & $9.89 \%$ & $14.18 \%$ & $5.71 \%$ \\
\hline 3 & $45.90 \%$ & $58.26 \%$ & $35.38 \%$ \\
\hline 4 & $14.72 \%$ & $17.34 \%$ & $10.58 \%$ \\
\hline 5 & $3.93 \%$ & $5.68 \%$ & $3.46 \%$ \\
\hline 7 & $7.18 \%$ & $9.39 \%$ & $5.71 \%$ \\
\hline 8 & $3.65 \%$ & $2.70 \%$ & $2.70 \%$ \\
\hline 9 & $39.00 \%$ & $42.72 \%$ & $28.42 \%$ \\
\hline 10 & $15.14 \%$ & $19.97 \%$ & $11.57 \%$ \\
\hline 11 & $10.87 \%$ & $12.72 \%$ & $9.95 \%$ \\
\hline 12 & $3.14 \%$ & $4.16 \%$ & $2.87 \%$ \\
\hline 13 & $32.44 \%$ & $46.35 \%$ & $27.55 \%$ \\
\hline 14 & $5.22 \%$ & $6.44 \%$ & $4.18 \%$ \\
\hline 15 & $0.62 \%$ & $1.56 \%$ & $0.12 \%$ \\
\hline Total & $4.83 \%$ & $9.74 \%$ & $3.97 \%$ \\
\hline
\end{tabular}

Source: author's calculation based on Annual Reports

quickly than the carrying amount of the leases assets. As the effect is expected for the individual leases, it is also expected for the mix of leases with different remaining lease terms - "portfolio effect" (IASB, 2016). The company 3 and 4 demonstrate the largest reduction in equity (-77.39\% and $-67.51 \%)$. However, median decrease is much lower $-3.65 \%$.

\section{Effects of IFRS 16 on Income Statement}

Under IAS 17, the expenses related to the operating leases are part of operating expenses. Unlike, IFRS 16 requires company to recognise interests on lease liability as a part of financial expenses and deprecation within a similar line item to that in which it presents depreciation of property, plant and equipment. It is clear that increase in interest expenses (financial expenses) and depreciation costs are assumed (Tabs. V and VI). In both items, the change is quite significant - more than $20 \%$.

Profit before interest and taxation (EBIT) will also increase applying new standard. The reason relates to interest expenses and where the expenses are reported. Under IFRS 16, EBITDA will be remarkably higher than under IAS 17 . This is because there will be not only increase in EBIT, but also in depreciation costs. Tab. VII and VIII confirm the previous assumption at all. At each example the growth is significant, especially at companies with major operating leases. EBIT and EBITDA are double higher in average applying IFRS 16. 
V: The effect of IFRS 16 on Interest expenses

\begin{tabular}{c|rrr}
\hline Company & Median & Maximum & Minimum \\
\hline 1 & $108.53 \%$ & $162.27 \%$ & $77.32 \%$ \\
\hline 2 & $32.58 \%$ & $59.86 \%$ & $21.13 \%$ \\
\hline 3 & $25.26 \%$ & $31.86 \%$ & $21.16 \%$ \\
\hline 4 & $33.54 \%$ & $37.18 \%$ & $14.20 \%$ \\
\hline 5 & $4.73 \%$ & $11.26 \%$ & $2.93 \%$ \\
\hline 7 & $19.10 \%$ & $38.56 \%$ & $13.88 \%$ \\
\hline 8 & $23.51 \%$ & $201.35 \%$ & $17.62 \%$ \\
\hline 9 & $165.10 \%$ & $228.10 \%$ & $78.29 \%$ \\
\hline 10 & $77.84 \%$ & $109.46 \%$ & $47.35 \%$ \\
\hline 11 & $20.35 \%$ & $87.94 \%$ & $13.93 \%$ \\
\hline 12 & $4.02 \%$ & $6.82 \%$ & $3.16 \%$ \\
\hline 13 & $30.06 \%$ & $104.17 \%$ & $20.13 \%$ \\
\hline 14 & $4.56 \%$ & $7.93 \%$ & $4.49 \%$ \\
\hline 15 & $1.10 \%$ & $4.37 \%$ & $0.12 \%$ \\
\hline Total & $4.96 \%$ & $11.83 \%$ & $3.78 \%$ \\
\hline Sour $\%$ & $23.51 \%$ & $38.56 \%$ & $14.20 \%$ \\
\hline
\end{tabular}

Source: author's calculation based on Annual Reports

VII: The effect of IFRS 16 on EBIT

\begin{tabular}{c|rrr}
\hline Company & Median & Maximum & Minimum \\
\hline 1 & $9.91 \%$ & $28.97 \%$ & $2.81 \%$ \\
\hline 2 & $4.27 \%$ & $10.70 \%$ & $2.52 \%$ \\
\hline 3 & $7.60 \%$ & $91.86 \%$ & $3.57 \%$ \\
\hline 5 & $10.26 \%$ & $40.73 \%$ & $4.47 \%$ \\
\hline 6 & $0.93 \%$ & $5.90 \%$ & $0.69 \%$ \\
\hline 7 & $0.95 \%$ & $2.42 \%$ & $0.62 \%$ \\
\hline 8 & $6.72 \%$ & $37.94 \%$ & $4.69 \%$ \\
\hline 9 & $70.03 \%$ & $385.00 \%$ & $10.68 \%$ \\
\hline 10 & $3.61 \%$ & $44.91 \%$ & $1.89 \%$ \\
\hline 11 & $4.70 \%$ & $25.78 \%$ & $2.11 \%$ \\
\hline 12 & $1.67 \%$ & $2.20 \%$ & $0.88 \%$ \\
\hline 13 & $11.66 \%$ & $32.39 \%$ & $6.45 \%$ \\
\hline 14 & $0.72 \%$ & $0.86 \%$ & $0.56 \%$ \\
\hline 15 & $0.45 \%$ & $2.39 \%$ & $0.03 \%$ \\
\hline Total & $11.52 \%$ & $107.14 \%$ & $3.05 \%$ \\
\hline
\end{tabular}

Source: author's calculation based on Annual Reports

\section{Effects of IFRS 16 on Key Financial Ratios}

The financial ratios are important source of information for investors, analysts and loan officers in analysing and evaluating the financial position of companies. Only examples of frequently used
VI: The effect of IFRS 16 on Depreciation costs

\begin{tabular}{c|rrr}
\hline Company & Median & Maximum & Minimum \\
\hline 1 & $116.12 \%$ & $184.26 \%$ & $68.22 \%$ \\
\hline 2 & $7.48 \%$ & $8.81 \%$ & $6.58 \%$ \\
\hline 3 & $340.50 \%$ & $440.34 \%$ & $235.52 \%$ \\
\hline 5 & $27.26 \%$ & $30.01 \%$ & $20.35 \%$ \\
\hline 6 & $12.03 \%$ & $18.65 \%$ & $10.17 \%$ \\
\hline 7 & $19.80 \%$ & $28.55 \%$ & $13.05 \%$ \\
\hline 8 & $20.54 \%$ & $46.58 \%$ & $13.47 \%$ \\
\hline 9 & $204.24 \%$ & $232.20 \%$ & $45.38 \%$ \\
\hline 10 & $126.63 \%$ & $138.20 \%$ & $6.58 \%$ \\
\hline 11 & $6.76 \%$ & $8.86 \%$ & $5.32 \%$ \\
\hline 12 & $215.88 \%$ & $250.54 \%$ & $139.10 \%$ \\
\hline 13 & $7.96 \%$ & $10.39 \%$ & $3.04 \%$ \\
\hline 14 & $0.34 \%$ & $1.04 \%$ & $0.08 \%$ \\
\hline 15 & $11.91 \%$ & $42.50 \%$ & $9.61 \%$ \\
\hline Total & $20.54 \%$ & $42.50 \%$ & $13.05 \%$ \\
\hline
\end{tabular}

Source: author's calculation based on Annual Reports

VIII: The effect of IFRS 16 on EBITDA

\begin{tabular}{|c|c|c|c|}
\hline Company & Median & Maximum & Minimum \\
\hline 1 & $105.98 \%$ & $234.00 \%$ & $12.18 \%$ \\
\hline 2 & $6.45 \%$ & $54.91 \%$ & $4.83 \%$ \\
\hline 3 & $163.40 \%$ & $271.20 \%$ & $59.89 \%$ \\
\hline 4 & $31.50 \%$ & $51.11 \%$ & $14.37 \%$ \\
\hline 5 & $7.24 \%$ & $15.39 \%$ & $5.00 \%$ \\
\hline 6 & $5.01 \%$ & $10.43 \%$ & $3.32 \%$ \\
\hline 7 & $28.06 \%$ & $76.73 \%$ & $12.71 \%$ \\
\hline 8 & $139.65 \%$ & $205.00 \%$ & $59.02 \%$ \\
\hline 9 & $55.36 \%$ & $111.66 \%$ & $20.89 \%$ \\
\hline 10 & $88.94 \%$ & $114.10 \%$ & $54.38 \%$ \\
\hline 11 & $4.37 \%$ & $5.14 \%$ & $3.54 \%$ \\
\hline 12 & $110.57 \%$ & $172.79 \%$ & $60.98 \%$ \\
\hline 13 & $2.93 \%$ & $4.32 \%$ & $1.84 \%$ \\
\hline 14 & $0.38 \%$ & $52.72 \%$ & $0.05 \%$ \\
\hline 15 & $13.54 \%$ & $40.29 \%$ & $9.69 \%$ \\
\hline Total & $28.06 \%$ & $54.91 \%$ & $12.18 \%$ \\
\hline
\end{tabular}

financial metrics, where the changes are expected, were chosen for the research. ROA and ROE are important performance measurement tools used to evaluate the companies' ability to generate income. The IFRS 16 will have a strong impact on the profitability ratios. Median decrease of ROA is 
IX: The effect of IFRS 16 on ROA using EBIT

\begin{tabular}{c|rrr}
\hline Company & Median & Maximum & Minimum \\
\hline 1 & $-31.37 \%$ & $-37.40 \%$ & $-18.08 \%$ \\
\hline 2 & $-2.49 \%$ & $-6.22 \%$ & $-1.84 \%$ \\
\hline 3 & $-47.19 \%$ & $-47.19 \%$ & $-47.19 \%$ \\
\hline 5 & $-20.94 \%$ & $-21.03 \%$ & $-20.85 \%$ \\
\hline 6 & $-18.65 \%$ & $-20.10 \%$ & $-16.76 \%$ \\
\hline 7 & $-8.41 \%$ & $-10.52 \%$ & $-6.19 \%$ \\
\hline 8 & $-34.86 \%$ & $40.02 \%$ & $-9.79 \%$ \\
\hline 9 & $-121.43 \%$ & $-207.47 \%$ & $-16.70 \%$ \\
\hline 10 & $-21.30 \%$ & $-21.30 \%$ & $-21.30 \%$ \\
\hline 11 & $-23.73 \%$ & $-30.14 \%$ & $-2.59 \%$ \\
\hline 12 & $-51.01 \%$ & $-7.25 \%$ & $4.79 \%$ \\
\hline 13 & $-4.85 \%$ & $-57.43 \%$ & $-38.98 \%$ \\
\hline 14 & $-0.08 \%$ & $-6.37 \%$ & $-2.34 \%$ \\
\hline 15 & $-9.70 \%$ & $-70.32 \%$ & $-8.40 \%$ \\
\hline Total & $-20.94 \%$ & $-21.30 \%$ & $-9.79 \%$ \\
\hline
\end{tabular}

Source: author's calculation based on Annual Reports

$-20.94 \%$ and median increase of ROE is $15.94 \%$. Nevertheless, larger growths are very frequent. Profit margin was added to possible comparison with previous case studies (Tab. XI). The current ratio was chosen as an example of liquidity ratio because it measures a company's ability to pay

XI: The effect of IFRS 16 on Profit Margin

\begin{tabular}{|c|c|c|c|}
\hline Company & Median & Maximum & Minimum \\
\hline 1 & $4.84 \%$ & $12.92 \%$ & $3.10 \%$ \\
\hline 2 & $6.11 \%$ & $15.40 \%$ & $2.64 \%$ \\
\hline 3 & $8.23 \%$ & $37.91 \%$ & $3.57 \%$ \\
\hline 4 & $10.26 \%$ & $40.73 \%$ & $4.47 \%$ \\
\hline 5 & $0.93 \%$ & $5.90 \%$ & $0.69 \%$ \\
\hline 6 & $0.95 \%$ & $2.42 \%$ & $0.62 \%$ \\
\hline 7 & $5.56 \%$ & $6.72 \%$ & $1.09 \%$ \\
\hline 8 & $129.76 \%$ & $285.60 \%$ & $10.68 \%$ \\
\hline 9 & $7.74 \%$ & $7.74 \%$ & $7.74 \%$ \\
\hline 10 & $20.50 \%$ & $83.49 \%$ & $2.11 \%$ \\
\hline 11 & $1.89 \%$ & $41.25 \%$ & $0.88 \%$ \\
\hline 12 & $13.58 \%$ & $79.50 \%$ & $6.45 \%$ \\
\hline 13 & $0.76 \%$ & $29.51 \%$ & $0.27 \%$ \\
\hline 14 & $17.03 \%$ & $92.83 \%$ & $0.03 \%$ \\
\hline 15 & $70.55 \%$ & $107.14 \%$ & $3.05 \%$ \\
\hline Total & $7.74 \%$ & $37.91 \%$ & $2.64 \%$ \\
\hline
\end{tabular}

Source: author's calculation based on Annual Reports
$\mathrm{X}$ : The effect of IFRS 16 on ROE using EBIT

\begin{tabular}{c|rrr}
\hline Company & Median & Maximum & Minimum \\
\hline 1 & $15.36 \%$ & $15.60 \%$ & $12.78 \%$ \\
\hline 2 & $7.18 \%$ & $11.83 \%$ & $3.58 \%$ \\
\hline 3 & $187.96 \%$ & $187.96 \%$ & $187.96 \%$ \\
\hline 5 & $172.68 \%$ & $292.86 \%$ & $52.49 \%$ \\
\hline 6 & $3.62 \%$ & $7.38 \%$ & $2.13 \%$ \\
\hline 7 & $2.28 \%$ & $4.25 \%$ & $1.86 \%$ \\
\hline 8 & $15.94 \%$ & $17.73 \%$ & $12.81 \%$ \\
\hline 9 & $33.36 \%$ & $80.78 \%$ & $25.40 \%$ \\
\hline 10 & $19.85 \%$ & $19.85 \%$ & $19.85 \%$ \\
\hline 11 & $93.66 \%$ & $217.22 \%$ & $45.62 \%$ \\
\hline 12 & $3.74 \%$ & $4.76 \%$ & $3.04 \%$ \\
\hline 13 & $85.09 \%$ & $124.40 \%$ & $49.90 \%$ \\
\hline 14 & $1.61 \%$ & $2.00 \%$ & $0.74 \%$ \\
\hline 15 & $0.35 \%$ & $2.56 \%$ & $0.06 \%$ \\
\hline Total & $17.23 \%$ & $23.45 \%$ & $15.02 \%$ \\
\hline
\end{tabular}

Source: author's calculation based on Annual Reports

short-term obligations. Decline of CR is caused by increase of lease liability while current assets do not. In contrast of ROA or ROE, adjustment is small about 7\% (Tab. XII).

Leverage ratios such as D/E, D/A ratios are the common measurements used to evaluate the

XII: The effect of IFRS 16 on Current Ratio

\begin{tabular}{c|ccc}
\hline Company & Median & Maximum & Minimum \\
\hline 1 & $-28.47 \%$ & $-21.54 \%$ & $-35.82 \%$ \\
\hline 2 & $-7.56 \%$ & $-5.40 \%$ & $-20.90 \%$ \\
\hline 3 & $-31.46 \%$ & $-26.13 \%$ & $-36.81 \%$ \\
\hline 5 & $-12.83 \%$ & $-9.57 \%$ & $-14.78 \%$ \\
\hline 6 & $-3.78 \%$ & $-3.35 \%$ & $-5.38 \%$ \\
\hline 7 & $-6.70 \%$ & $-5.40 \%$ & $-8.59 \%$ \\
\hline 8 & $-7.77 \%$ & $-0.64 \%$ & $-14.30 \%$ \\
\hline 9 & $-28.06 \%$ & $-22.13 \%$ & $-29.93 \%$ \\
\hline 10 & $-13.15 \%$ & $-10.37 \%$ & $-16.65 \%$ \\
\hline 11 & $-9.81 \%$ & $-9.05 \%$ & $-12.61 \%$ \\
\hline 12 & $-3.04 \%$ & $-2.79 \%$ & $-3.99 \%$ \\
\hline 13 & $-24.49 \%$ & $-21.60 \%$ & $-31.67 \%$ \\
\hline 14 & $-0.96 \%$ & $-2.70 \%$ & $-6.05 \%$ \\
\hline 15 & $-4.61 \%$ & $-3.82 \%$ & $-8.88 \%$ \\
\hline Total & $-7.77 \%$ & $-5.40 \%$ & $-14.30 \%$ \\
\hline
\end{tabular}

Source: author's calculation based on Annual Reports 
XIII: The effect of IFRS 16 on $D / E$

\begin{tabular}{|c|c|c|c|}
\hline Company & Median & Maximum & Minimum \\
\hline 1 & $123.3 \%$ & $144.41 \%$ & $50.98 \%$ \\
\hline 2 & $15.72 \%$ & $18.40 \%$ & $10.00 \%$ \\
\hline 3 & $272.82 \%$ & $272.82 \%$ & $272.82 \%$ \\
\hline 4 & $220.27 \%$ & $344.98 \%$ & $95.55 \%$ \\
\hline 5 & $33.07 \%$ & $43.37 \%$ & $18.29 \%$ \\
\hline 6 & $21.05 \%$ & $25.50 \%$ & $1.77 \%$ \\
\hline 7 & $112.92 \%$ & $142.81 \%$ & $36.96 \%$ \\
\hline 8 & $226.14 \%$ & $372.10 \%$ & $70.26 \%$ \\
\hline 9 & $72.00 \%$ & $73.00 \%$ & $72.00 \%$ \\
\hline 10 & $127.84 \%$ & $335.08 \%$ & $83.75 \%$ \\
\hline 11 & $9.53 \%$ & $14.57 \%$ & $7.13 \%$ \\
\hline 12 & $202.09 \%$ & $257.98 \%$ & $97.10 \%$ \\
\hline 13 & $10.37 \%$ & $13.09 \%$ & $4.42 \%$ \\
\hline 14 & $0.55 \%$ & $0.71 \%$ & $0.12 \%$ \\
\hline 15 & $10.38 \%$ & $14.98 \%$ & $8.71 \%$ \\
\hline Total & $72.00 \%$ & $73.00 \%$ & $41.00 \%$ \\
\hline
\end{tabular}

Source: author's calculation based on Annual Reports

liquidity of the companies and to understand the financing method of the companies. Rise of financial liability and at the same time decrease in equity, which is smaller than growth of the debt, lead to increase of D/E. Similar situation is applied for D/A where both parametric increased. Growth of D/A is not so significant as D/E (Tab. XIII and XIV). As in previous tables, the biggest changes are seen at the companies with major operating leases.

\section{DISCUSSION}

Most of the researches focusing on impacts of IFRS 16 are quite theoretic. The effects are described only in the way that some financial item on financial statement or metrics would increase or decrease without numeric change. For this reason, the case studies focusing on effects of lease capitalization were also chosen for the comparison. Each of the research distinguishes in number of examined entities, countries where the research is made or observed financial ratios. The frequent impossibility of comparing results is also due to a different range of surveyed indicators and different assumptions that have been included.

The research of Joshi and Wong (2015) follows the method of constructive capitalisation developed by Imhoff et al. (1991) to demonstrate the potential impacts of the new rules on financial ratios and financial statements of 107 Australian companies from the different sectors of the economy. Bennett and Bradbury (2003) examined 38 companies listed on the New Zealand Stock Exchange in the year
XIV: The effect of IFRS 16 on $D / A$

\begin{tabular}{|c|c|c|c|}
\hline Company & Median & Maximum & Minimum \\
\hline 1 & $20.93 \%$ & $26.03 \%$ & $9.67 \%$ \\
\hline 2 & $6.35 \%$ & $7.20 \%$ & $0.53 \%$ \\
\hline 3 & $3.75 \%$ & $3.75 \%$ & $3.75 \%$ \\
\hline 4 & $0.90 \%$ & $1.49 \%$ & $0.31 \%$ \\
\hline 5 & $6.50 \%$ & $9.15 \%$ & $3.26 \%$ \\
\hline 6 & $6.92 \%$ & $9.61 \%$ & $6.10 \%$ \\
\hline 7 & $19.63 \%$ & $23.71 \%$ & $9.53 \%$ \\
\hline 8 & $8.93 \%$ & $21.54 \%$ & $3.57 \%$ \\
\hline 9 & $12.95 \%$ & $12.95 \%$ & $12.95 \%$ \\
\hline 10 & $4.39 \%$ & $7.70 \%$ & $0.03 \%$ \\
\hline 11 & $1.55 \%$ & $1.83 \%$ & $0.59 \%$ \\
\hline 12 & $13.60 \%$ & $18.25 \%$ & $6.28 \%$ \\
\hline 13 & $3.37 \%$ & $4.07 \%$ & $1.23 \%$ \\
\hline 14 & $0.06 \%$ & $0.19 \%$ & $0.02 \%$ \\
\hline 15 & $3.51 \%$ & $4.85 \%$ & $2.53 \%$ \\
\hline Total & $6.35 \%$ & $7.70 \%$ & $3.26 \%$ \\
\hline
\end{tabular}

of 1995. Kilpatrick and Wilburn (2006) replicated the study of Imhoff et al. (1991) and used the nine companies from the study in 2004 to re-examine the lease capitalization effect in the financial statements. Lipe and Wright (1991) selected seven American companies for their study, where the ratio of the cash flow from operating leases to the total assets of the companies was very high, and these companies were subsequently supplemented by another seven companies, where the ratio was relatively low. For this reason, there are 2 results in the summary table (Tab. XV) The research of Beattie et al. (1998) focused on 232 industrial and commercial companies listed in U.K. using capitalization model based on Imhoff et al.'s model from the year 1991. De Villiers a Middelberg (2013) chose for their research 40 top Johannesburg Stock Exchange listed companies. The following table concludes author's results and the results of the mentioned researches.

Comparing the author's results, it is possible to summarize that most of them achieved higher values. Good example is change in total assets, total liabilities or ROE where the author's median was several times higher. On the contrary, financial metrics of indebtedness such as D/E and D/A were nearly similar. The biggest difference can be seen in ROA. ROA is equal to total assets divided by EBIT. So, if both items increase and numerator more than divisor, it leads to the increase in ROA. Duke et al. (2009) divided their sample of companies into positive and negative income groups and found out significant differences in the changes 
$\mathrm{XV}$ : Comparison table

\begin{tabular}{l|c|c|c|c|c|c|c}
\hline \multicolumn{1}{c}{ Metric } & Median & Joshi. Wong & Bennet. Bradbury & Kilpatrick.Wilburn & Imhoff et al. (1991) & Beattie & De Villiers \\
\hline Total Assets & $25.17 \%$ & $3.74 \%$ & $5.20 \%$ & NO & NO & $39.00 \%$ & NO \\
\hline Total Liabilities & $40.82 \%$ & $4.34 \%$ & $11.70 \%$ & NO & NO & $6.39 \%$ & NO \\
\hline Total equity & $-3.65 \%$ & $-0.27 \%$ & $-1.60 \%$ & $-30.00 \%$ & NO & NO & NO \\
\hline ROA & $-20.94 \%$ & $-15.35 \%$ & NO & NO & $-10.80 \%$ & $-10.80 \%$ & $-20.00 \%$ \\
\hline ROE & $15.94 \%$ & $-1.23 \%$ & NO & NO & NO & $4.80 \%$ & $-15.00 \%$ \\
\hline D/E & $72.00 \%$ & $31.69 \%$ & NO & $171.60 \%$ & $47 \%, 191 \%$ & $48.70 \%$ & $9.00 \%$ \\
\hline D/A & $6.35 \%$ & $10.11 \%$ & $13.39 \%$ & NO & NO & NO & $8.00 \%$ \\
\hline
\end{tabular}

Source: author's calculation based on Annual Reports

of ROA between the positive and negative income subgroups. The ROA decreased for the negative income sub-group, but increased for the positive income sub-group. The author does not know the exact composition of the companies which were included in the previous researches. Case study of IASB (2016) is the only research applying IFRS 16 and focused on airlines. Unfortunately the number of metrics is small. The author's median change in EBITBA is $111.87 \%$ and IASB‘s $40.03 \%$. Similar results can be found at Profit Margin where author's median change is $101.67 \%$ and IASB's is only $25.03 \%$. Generally, differences in results may be based also on fact that the comparing studies (except of IASB, 2016) did not work with IFRS 16 but used capitalization model with different subjective assumptions.

\section{CONCLUSION}

The current lease accounting principles are characterized by a number of problems. The biggest problem is the existence of two different accounting models for financial and operating leases. Different approaches do not allow the necessary comparability of company financial statements and the individual users of the financial statements are forced to make subjective capitalization of operating leases. IASB and FASB were working on convergence project which ended in January 2017 when IASB published new Leases standard IFRS 16 which supersedes IAS 17 Leases and its related interpretations.

The main objective of this study was to determine the significance of the effect of IFRS 16 on the financial statements and financial ratios of the fifteen European airlines. The biggest impact is expected on companies where operating leases are major sources of funding such as aviation industry. IFRS 16 will result in a number of line items and financial ratios to increase or decrease as it reflects newly the right-of-use asset and the lease liability. The research has shown a significant effect of IFRS 16. The results confirmed assumed increase in total assets, non-current liabilities and decrease in shareholders' equity. However, the changes in the financial statements are mores significant as the changes found in prior studies. The capitalization of operating lease under IFRS 16 leads to increase of indebtedness and D/E and D/A ratios. The financial ratios shown profitability such as ROA and ROE will change significantly under new lease standard. The paper also confirmed that impacts of IFRS 16 will be strongly seen at the companies with major off balance sheet leases. The new standard IFRS 16 revises the definition of a lease that deferred from the definition in IAS 17. IAS 17 paid attention to risk and rewards and on the contrary IFRS 16 puts emphasis on controlling the use of the object of the lease. This means that the lessee must have the exclusive right to use the leased asset for a certain period of time and at the same time the lessee can decide how the object will be treated. This point can be very problematic in the transport and logistics sector. The second problem in this industry it may be the fact that lease contracts very often include both the lease itself and the regular service of the leased asset. According to IFRS 16, these matters need to be reported separately. As a result of these changes some existing lease contracts may not be newly recognized as the leases. It is obvious that application of IFRS 16 will have strong effect on company's financial statement and key financial metrics. So it will be important to find a way how to interpret the new financial results to investors. 


\section{REFERENCES}

BEATTIE, V., EDWARDS, K. and GOODACRE, A. 1998. The impact of constructive operating lease capitalization on key accounting ratios. Accounting and Business Research, 28(4): 233-254.

BENNET, B. K., BRADBURY, M. E. 2003. Capitalising non-cancelable operating leaese. Journal of International Financial Management and Accounnting, 14(2): 101-114.

DUKE, F. and SU, J. 2012. Evaluating Constructive Lease Capitalization and Off-Balance-Sheet Financing: An Instructional Case with FedEx and UPS. Accounting Perspectives, 11(1): 57-69.

DUKE, J. C., HSIEH, S. J. and SU, Y. 2009. Operating and synthetic leases: Exploiting Financial benefits in the post-Enron era'. Advances in International Accounting, 25: 28-39.

DE VILLIERS, R. R. and MIDDELBERG, S. L. 2013. Determining the impact of capitalising long-term operating lease on the financial ratios of the top 40 JSE -listed companies. International Business \& Economics Resereach Journal, 12(6): 655-669.

FELDMAN, A. 2002. Off balance. Money, 31(4): 46-47.

FITO, M. ANGELS, MOYA, S. and ORGAZ, N. 2011. Impact assessment of recognition versus note disclosure in operating leases. Aeca. [Online]. Available at: http://www.aeca.es/pub/on_line/ comunicaciones_xvicongresoaeca/cd/121a.pdf [Accessed: 2012, January 15].

FRANZEN, L. A., KIMBERLY, J. L. and SIMIN, T. T. 2009. Capital Structure and the Changing Role of Off - Balance - Sheet Lease Financing. [Online]. Available at: http://www.frbatlanta.org/filelegacydocs/ seminars/seminar_simin_101609.pdf [Accessed: 2009, August 15].

FÜLBIER, R., SILVA, J. and PFERDEHIRT, M. 2008. Impact of lease capitalization on Financial ratios of Listed German Companies. Schmalenbach Business Review, 60(2): 122-144.

IASB. 2016. IFRS 16 Leases Effect Analysis. Ifrs. [Online]. Available at: www.ifrs.org/-/media/.../leases/ ifrs/.../ifrs16-effects-analysis.pdf [Accessed: 2016, January 15].

IMHOFF, E. A., LIPE, R. C. and WRIGHT, D. W. 1991. Operating Leases: Impact of Constructive Capitalization. Accounting Horizons, 5(1): 51-63.

IMHOFF, E. A., LIPE, R. C. and WRIGHT, D. W. 1997. Operating leases: Income effects of constructive capitalization. Accounting Horizons, 11(2): 12-32.

KILPATRICK, B. G. and WILBURN, N. L. 2006. Off balance sheet financing and operating lease: Impact on lessee financial ratios. RMA Journal, 89(4): 80-87.

LUBOVE, S. and MACDONALD, E. 2002. Debt? Who, me? Enron is hardly alone when it comes to Creative Off-Balance sheet Accounting. Forbes. [Online]. Available at: https://www.forbes.com/ forbes/2002/0218/056.html\#6d35f1641a96 [Accessed: 2016, January 15].

PWC. 2016. A study on the impact of lease capitalisation IFRS 16: The new leases standard. [Online]. Available at: https://www.pwc.com/.../a-study-on-the-impact-of-lease-capitalisation.pdf [Accessed: 2016, February].

TOCCI, G. 2016. Airlines' Choice: Leasing vs. Buying. Airlines' Choice: Leasing vs. Buying. [Online]. Available at: https://www.brookfieldav.com/single-post/2016/09/09/Airlines\%E2\%80\%99-ChoiceLeasing-vs-Buying [Accessed: 2016, September 9].

WONG, K. and MAHESH, J. 2015. The Impact of Lease Capitalisation on Financial Statements and Key Ratios: Evidence from Australia. Australasian Accounting, Business and Finance Journal, 9(3): 27-44. 